\title{
The Assays of Bacteria-Yeast Consortia as Probiotics Candidates and Their Influences on Nutrients Utilization of Quails Diet
}

\author{
A. Sofyan ${ }^{\mathrm{a}, *}$, R. S. H. Martin ${ }^{\text {b }}$, E. B. Laconi ${ }^{\mathrm{b}}$, A. Jayanegara ${ }^{\mathrm{b}}$, H. Julendra ${ }^{a}$, E. Damayanti $^{\mathrm{a}}$, \& A. E. Suryani ${ }^{\mathrm{a}}$ \\ a Research Group of Bio-Feed Additive Technology, Research Division for Natural Product Technology (BPTBA), \\ Indonesian Institute of Sciences (LIPI) \\ Jalan Jogja-Wonosari Km. 31.5 Gading, Playen, Gunungkidul, D.I. Yogyakarta 55861, Indonesia \\ ${ }^{\mathrm{b}}$ Department of Nutrition and Feed Technology, Faculty of Animal Sciences, \\ IPB University (Bogor Agricultural University) \\ Jalan Agatis, Kampus IPB Darmaga Bogor 16680, Indonesia \\ *Corresponding author: ahmad.sofyan@lipi.go.id / sofyan_lipi@yahoo.co.id \\ (Received 25-02-2019; Revised 09-04-2019; Accepted 03-05-2019)
}

\begin{abstract}
This study aimed to assay L. plantarum (P1), S. cerevisiae (P2), and its combination (P3) as probiotics candidates and their effects on nutrient digestibility in Japanese quails (Cortunix cortunix japonica) diets. In vitro assays were employed to evaluate the antibacterial activities against pathogenic bacteria (Escherichia coli, Staphylococcus aureus, Pseudomonas aeruginosa, and Salmonella pullorum), sensitivity to antibiotics (i.e., streptomycin, penicillin, and erythromycin), stress on bile salt and acidity condition. Evaluation of probiotics on in vivo nutrient utilization was carried out by administration of probiotics to laying quails in drinking water with various treatments (R0, control; $\mathbf{R} \mathbf{1}$, L. plantarum; $\mathbf{R} 2$, S. cerevisiae; R3, combination of R1+R2; R4, commercial feed additive). Results showed that the highest inhibitory activity was performed by $P 2$ on $S$. aureus $(17.28 \mathrm{~mm})$. Treatments P2 and P3 were resistant to all the tested antibiotics, while P1 was resistant to streptomycin and penicillin. P1 was tolerant to bile salts whereas P2 was tolerant to gastric acidity conditions. For the in vivo experiment, quails fed R1, R2, and $\mathrm{R} 4$ had higher nitrogen retention as compared to R0 $(\mathrm{p}<0.05)$. However, all treatments revealed similar metabolizable energy values. The cluster analysis showed that quails consuming the combination of $L$. plantarum and S. cerevisiae were within the same cluster with the control but different clusters from the individual probiotics across all parameters, indicating a possible antagonistic effect between the two species. In conclusion, the inclusion of L. plantarum or S. cerevisiae inhibits pathogenic bacteria without influencing nutrient utilization of quail diet.
\end{abstract}

Keywords: antibiotic growth promoters; inhibitory activity; lactic acid bacteria; microbial feed additive; quails

\section{INTRODUCTION}

Antibiotic growth promoters (AGPs) is commonly used as feed additive to enhance poultry performance. However, dietary inclusion of AGPs had a negative effect on poultry such as the resistance of pathogenic bacteria in gastrointestinal tract (GIT) and antibiotic residue in poultry products (Huyghebaert et al., 2011). In 2006, AGPs was banned in the European Union countries (Ronquillo \& Hernandez, 2017), followed by some ASEAN countries (Goutard et al., 2017) including Indonesia has also banned AGPs use for animal feed in early 2018 by implementation of the animal medicine classification act (MARI, 2017).

Exploration of probiotics candidate as an alternative feed additive for replacing AGPs had been conducted by many researchers in the current decade. Probiotic are live and nonpathogenic microbes, which have a positive impact on the host animal by optimizing gut microbiota existence and modulating the immune system (Cox \& Dalloul, 2015). Probiotics are microorgan- isms that contribute to the balance of microflora in the digestive tract by increasing the good microbial population (Sharifi et al., 2012; Rajoka et al., 2018). Indigenous probiotic candidates isolated from the digestive tract of Indonesian native chicken potentially improve performance of broiler (Harimurti \& Hadisaputro, 2015). Probiotics possibly interrelate with the gut-associated lymphoid tissue and enhance immune modulating system to minimize pathogenic infection (Arena et al., 2018). Probiotics might be associated with the composition of their indigenous internal microbes.

Lactic acid bacteria (LAB) are commonly used as a probiotic that has ability to prevent the colonization of pathogenic bacteria on GIT and it survives on GIT especially on acid condition and bile salt (Rajoka et al., 2018). Acidic condition is the most constrain for probiotic viability to enter GIT. The probiotic microbe has to survive in bile salt stress in small intestine. Some studies of the LAB abilities are known to have high activity in inhibiting pathogenic bacteria and proven to survive in the gastrointestinal tract. 
In the previous study, S. cerevisiae has a potency to reduce cholesterol accumulation in the animal product (Istiqomah et al., 2018). Yeast positively interacts with bacteria by producing amino acids and vitamins for stimulating bacterial growth (Hatoum et al., 2012). However, application of LAB and yeast as probiotics consortia is still rarely elucidated. We proposed a hypothesis that probiotic containing consortium of $\mathrm{LAB}$ and yeast generates synergistic effect on the host animals. This study aimed to evaluate antibacterial activity and viability of probiotics candidate consisting of L. plantarum AKK-30, S. cerevisiae B-8, and their combinations as well as the possibility interaction activity to improve energy and protein utilization of quail diet.

\section{MATERIALS AND METHODS}

\section{In Vitro Assessment for Viability and Antimicrobial Activity}

Isolate and sample preparation. Isolates used in this experiment consisted of Lactobacillus plantarum AKK-30 (isolated from native chicken) and Saccharomyches cerevisiae B-18 (isolated from Javanese duck) were molecularly identified by Julendra et al. (2017) and Istiqomah et al. (2018), respectively. Pathogenic bacteria used in the in vitro assay were Salmonella pullorum ATCC 13036, Pseudomonas aeruginosa FNCC 0063, Staphylococcus aureus FNCC 6049, Escherichia coli FNCC 0194. The selective medium for growing the isolates consisted of de Mann Rogosa Sharpe agar (MRSA) (Oxoid), chloramphenicol yeast glucose agar (CYGA) (Merck). Nutrient agar (NA) (Merck) was used as a universal medium for assaying consortia of both isolates.

In vitro assay of probiotics consisting of tolerance to acid condition, gastric juice, and bile salt were carried out according to Torshizi et al. (2008) and Damayanti et al. (2014). Acid tolerance assays were arranged on the factorial design $(4 \times 3 \times 2)$ consisted of four probiotic treatments $(\mathrm{Lp}=$ L. plantarum $\mathrm{AKK} 30 ; \mathrm{Sc}=$ S. cerevisiae B-8, Consortia Lp, and Consortia Sc), three incubation time $(0,45$, and $90 \mathrm{~min})$, and two $\mathrm{pH}$ medium $(\mathrm{pH} 2$ and 3) with three replications. At 18-hours incubation, the media containing isolates were centrifuged with the speed of $4136 \times g$ at $4^{\circ} \mathrm{C}$ for 10 minutes. The pellet was cleared from using PBS 2 times. Pellet suspension was added each to $990 \mu \mathrm{L}$ sterile PBS at $\mathrm{pH} 2$ and $\mathrm{pH} 3$.

Antimicrobial and antibiotic sensitivity assay were conducted by using the agar diffusion method (Bonev et al., 2008). The antimicrobial assay was arranged in a factorial design with treatments factors $(6 \times 4)$ were antimicrobial substances (Lp, Sc, Lp+Sc, streptomycin, penicillin. and erythromycin) and pathogenic bacteria (Sp, Sa, Pa, Ec) with three replications. Antibiotic sensitivity was arranged in a completely randomized design with treatment factors ( $3 \times 3)$; three isolates (Lp, Sc, and $\mathrm{Lp}+\mathrm{Sc}$ ), three antibiotics, and each treatment consisted of three replications. Antimicrobial substance of isolates was harvested from each inoculated media. After $24 \mathrm{~h}$ of incubation, MRSB inoculated L. plantarum AKK-30 $\left(37^{\circ} \mathrm{C}\right)$, and CYGB inoculated S. cerevisiae $\left(30^{\circ} \mathrm{C}\right)$ centrifuged at $4136 \times \mathrm{g}$ of $4{ }^{\circ} \mathrm{C}$ for 15 minutes. The supernatant neutralized with $\mathrm{NaOH} 1 \mathrm{M}(25 \mu \mathrm{L}, \mathrm{pH}=7)$ was dripped onto a blank disc paper that had been placed on the top of media of the inoculated pathogenic bacteria.

Gastric juice tolerant assay was conducted according to Torshizi et al. (2008). Briefly, L. plantarum was cultured on MRSB for $18 \mathrm{~h}$ at $37^{\circ} \mathrm{C}$ and S. cerevisiae was cultured on CYGB for $18 \mathrm{~h}$ at $30^{\circ} \mathrm{C} .1 \mathrm{~mL}$ of each culture was centrifuged at $4136 \times \mathrm{g}$ for $10 \mathrm{~min}$ at $4{ }^{\circ} \mathrm{C}$. The pellet was rinsed by sterilized PBS, diluted in $0.3 \mathrm{~mL}$ of PBS, mixed with $1 \mathrm{~mL}$ of PBS $\mathrm{pH} 2$ containing pepsin $0.3 \%$ (artificial gastric juice). The cultures were sampled at 0 , 15 , and $45 \mathrm{~min}$ after incubation at $37^{\circ} \mathrm{C}$ and $30^{\circ} \mathrm{C}$ for $L$. plantarum and $S$. cerevisiae, respectively.

In bile salt tolerant assay, the pellet was similarly prepared with gastric juice salt tolerant assay. The diluted pellet in $0.3 \mathrm{~mL}$ of PBS was mixed with $1 \mathrm{~mL}$ PBS containing $0.3 \%(\mathrm{w} / \mathrm{v})$ bile salt. The cultures were sampled at 0,120 , and $180 \mathrm{~min}$ after incubation at $37^{\circ} \mathrm{C}$ and $30^{\circ} \mathrm{C}$ for L. plantarum and S. cerevisiae, respectively. This assessment was arranged on the factorial design (4 $x 3$ ) consisted of four isolates and three observation time with three replications.

\section{In Vivo Assay on Nutrients Digestibility}

Animal, quail diet, and feed additive. Female Japanese quails (Cortunix cortunix japonica) at 3 weeks of age were used in this experiment. Quail's diet was formulated according to nutrient requirement of Japanese quails according to the Indonesian National Standard (SNI) No. 01-3907-2006) presented in Table 1. Probiotic L. plantarum was prepared by spraying-drying method (BarbosaCánovas et al., 2005) using milk skim carrier and S. cerevisiae B-18 was prepared by oven-dried method (AOAC, 2005) using cassava flour as a carrier.

Treatments and feeding trials. The experiment for evaluating nutrient digestibility was conducted in the Poultry Closed House, Bio-Feed Additive Technology Laboratory, Research Unit for Natural Product Technology (BPTBA), Indonesian Institute of Sciences (LIPI), Yogyakarta. The experimental protocol had been approved by the Commission of Ethical Clearance for Pre-clinical Experiment (No. 00136/04/LPPT/XI/2017), from the Integrated Laboratory of Research and Testing (LPPT), Universitas Gadjah Mada (UGM), Yogyakarta.

One hundred and fifty (150) female quails were randomly distributed into five treatments; R0) control, R1) L. plantarum, R2) S. cerevisiae, R3) R1+R2, R4) commercial probiotic. Each treatment consisted of six cages as replications and five birds in each cage. Fifteen female birds were randomly distributed in three cages as indigenous control. The experimental birds were reared and adapted from early-laying to after peak-laying period ( $40 \mathrm{~d}$ to $90 \mathrm{~d}$ of age) by feeding diets and drinking water according to the treatments. Measurement of nutrient digestibility was conducted by modification of the method used by Farrell et al. (1982). Briefly, each bird was fed quail's diet (35 g of feed per bird). The treated group was administrated probiotic by diluting in the drinking water (3.5 $\mathrm{mg}$ per bird). The probiotics used contained $7.8 \times 10^{8} \mathrm{cfu} / \mathrm{g}$ for L. plantarum AKK-30 and 
$5.3 \times 10^{6} \mathrm{cfu} / \mathrm{g}$ for S. cerevisiae B-18. The manure excreta were collected during $24 \mathrm{~h}$, immediately dried at $55^{\circ} \mathrm{C}$ for $48 \mathrm{~h}$, and packed for further chemical analysis.

Analyzing metabolizable energy and nitrogen retention. The energy content of samples (feed and manure) was estimated by the Parr ${ }^{\circledR} 6200$ bomb calorimeter (Parr Instrument Company, USA), while crude protein of samples was analyzed by Kjeldahl methods (AOAC, 2005). Metabolizable energy (ME) and nitrogen retention (NR) were estimated according to the Sibbald \& Wolinetz (1985).

\section{Statistical Analysis}

Data from in vitro and in vivo assays were statistically analyzed using analysis of variance (ANOVA). Significance difference was declared if the treatment differed at least $5 \%$, and continued to post hoc test

Table 1. Ingredient and nutrient composition of quail's diets

\begin{tabular}{lc}
\hline \multicolumn{1}{c}{ Ingredients } & Content $(\%)$ \\
\hline Corn & 55.10 \\
Soy bean meal & 30.50 \\
Meat bone meal & 4.00 \\
Crude palm oil & 2.80 \\
Premix & 0.10 \\
DCP & 0.80 \\
Salt & 0.10 \\
Limestone & 5.70 \\
L-Lysine & 0.70 \\
DL-Methionine & 0.20 \\
\hline Total & 100.00 \\
\hline Dry matter (\%) & 88.96 \\
Ash (\%) & 10.20 \\
Crude protein (\%) & 17.93 \\
Crude fiber (\%) & 5.36 \\
Ether extract (\%) & 5.08 \\
Nitrogen-free extract (\%) & 50.39 \\
Calcium (\%) & 3.38 \\
Phosphorus (\%) & 0.68 \\
NaCl (\%) & 0.39 \\
Gross energy (kcal kg-1) & 3552 \\
\hline
\end{tabular}

using Duncan multiple range test to compare differences among treatments which used Costat Statistical Software (Cohort, 2008). The logarithmic transformation was applied to convert bacteria cell count $(\mathrm{cfu} / \mathrm{mL})$ into logarithmic value of incubation $(\log 10 \mathrm{cfu} / \mathrm{mL})$. Part of in vitro assay parameters were retrieved from previous study (Martin et al., 2018) and deeply analyzed and elaborated in this experiment. In order to evaluate relationship between parameters in the in vivo experiment, relative value (\%) of NR and ME data were analyzed using hierarchical cluster analysis (HCA) (Zhang et al., 2017) and visualized in dendro-heatmap by the R-statistical software (R Core Team, 2015).

\section{RESULTS}

\section{In Vitro Assessment Characteristic of Probiotic Candidate}

Antibacterial activities assays of antibacterial substances of isolates and antibiotic (as a positive control) against pathogenic bacteria are shown in Table 2. Both isolates generated inhibition activity at different levels. Inhibition activity of $S$. cerevisiae was higher than that of L. plantarum. There was a significant interaction $(p<0.01)$ between pathogenic bacteria and antibacterial substances. The highest inhibition was found in supernatant obtained from the $S$. cerevisiae B-18 against $S$. aureus, followed by those obtained from $P$. aeruginosa and S. pullorum. However, supernatant obtained from combination of all isolates did not inhibit E. coli growth (Table 2). Susceptibilities of the isolates to antibiotics showed that yeast had no clearing zone after 24 hours of incubation while L. plantarum had different resistance levels on each antibiotic. L. plantarum was categorized as sensitive microorganism to erythromycin while L. plantarum combined with $S$. cerevisiae showed the resistant response to all antibiotics (streptomycin, penicillin, and erythromycin) (Table 3).

Acidic condition ( $\mathrm{pH} 2$ and 3) and the duration of incubation significantly influenced isolates viabilities. The viability of isolate $S$. cerevisiae was higher than that of L. plantarum. Population of S. cerevisiae in $\mathrm{pH} 2$ medium was lower $(\mathrm{p}<0.05)$ than that in $\mathrm{pH} 3$ medium whereas populations of L. plantarum in $\mathrm{pH} 2$ and $\mathrm{pH} 3$ were similar. The viability of $S$. cerevisiae and its consor-

Table 2. Antimicrobial activities of crude bacteriocin and commercial antibiotic on pathogenic bacteria

\begin{tabular}{|c|c|c|c|c|}
\hline \multirow{2}{*}{ Antimicrobial substances } & \multicolumn{4}{|c|}{ Diameter of clearing zone $(\mathrm{mm})^{\mathrm{a}}$} \\
\hline & P. aeruginosa & S. aureus & E. coli & S. pullorum \\
\hline \multicolumn{5}{|l|}{ Antibiotic } \\
\hline Streptomycin & $11.19 \pm 2.61^{\mathrm{de}}$ & $11.20 \pm 0.46^{\mathrm{de}}$ & $6.18 \pm 0.93^{\mathrm{gh}}$ & $13.01 \pm 0.16^{\mathrm{cd}}$ \\
\hline Penicillin & $15.06 \pm 3.18^{\mathrm{bc}}$ & $13.34 \pm 0.23^{\text {cd }}$ & $0.00 \pm 0.00^{\mathrm{i}}$ & $16.76 \pm 3.49^{b}$ \\
\hline Erythromycin & $17.69 \pm 0.63^{b}$ & $27.52 \pm 0.65^{\mathrm{a}}$ & $9.97 \pm 0.88^{\text {ef }}$ & $11.90 \pm 2.15^{\text {de }}$ \\
\hline \multicolumn{5}{|l|}{ Supernatant } \\
\hline Lp AKK-30 & $9.84 \pm 2.98^{\text {ef }}$ & $6.44 \pm 3.13^{\text {gh }}$ & $0.00 \pm 0.00^{\mathrm{i}}$ & $7.29 \pm 0.96^{\mathrm{fg}}$ \\
\hline Sc B-18 & $15.46 \pm 1.60^{\mathrm{bc}}$ & $17.82 \pm 2.59^{b}$ & $0.00 \pm 0.00^{\mathrm{i}}$ & $15.04 \pm 2.37^{\mathrm{bc}}$ \\
\hline Lp AKK-30+ Sc B-18 & $4.49 \pm 0.12^{\mathrm{gh}}$ & $4.00 \pm 0.09^{\mathrm{h}}$ & $0.00 \pm 0.00^{\mathrm{i}}$ & $4.18 \pm 0.24^{\mathrm{gh}}$ \\
\hline
\end{tabular}

Note: *Means in the same column or row with different superscripts differ significantly $(\mathrm{p}<0.05)$. 
Table 3. Antibiotic sensitivity test on the probiotic inoculated media ( $\mathrm{mm}$ )

\begin{tabular}{lccc}
\hline \multicolumn{1}{c}{$\begin{array}{c}\text { Isolate } \\
\text { (Medium) }\end{array}$} & \multicolumn{3}{c}{ Antibiotics } \\
\cline { 2 - 4 } $\begin{array}{l}\text { Lp AKK-30 } \\
\text { (MRSA) }\end{array}$ & Streptomycin & Penicillin & Erythromycin \\
$\begin{array}{l}\text { Sc B-18 } \\
(\text { CYGA) }\end{array}$ & $0.00 \pm 0.00(\mathrm{R})$ & $23.11 \pm 0.73(\mathrm{R})$ & $24.18 \pm 1.04(\mathrm{~S})$ \\
$\begin{array}{l}\text { Lp+Sc } \\
(\mathrm{MRSA})\end{array}$ & $0.00 \pm 0.00(\mathrm{R})$ & $0.00 \pm 0.00(\mathrm{R})$ & $0.00 \pm 0.00(\mathrm{R})$ \\
$\begin{array}{l}\text { Lp+Sc } \\
(\mathrm{CYGA})\end{array}$ & $0.11 \pm 0.01(\mathrm{R})$ & $0.43 \pm 0.07(\mathrm{R})$ \\
\hline
\end{tabular}

Note: R: Resistant, S: Sensitive. tia was higher than those of the others at $\mathrm{pH} 3$ after $45 \mathrm{~h}$ of incubation (Table 4). The isolate of L. plantarum and their consortia were tolerant to bile salt condition during 180 minutes of incubation while S. cerevisiae and their consortia were viable in gastric juice during 45 minutes of incubation (Table 5).

\section{Effect of Probiotic Inclusion on Nutrients Digestibility}

Nutrient digestibility of quail's diets treated by probiotic is presented in Table 5 . The values of nitrogen retention (NR) and metabolizable energy (ME) were not affected by treatments (Table 6). Quails treated by a combination of L. plantarum and S. cerevisiae were within

Table 4. Viability of probiotic isolates on the acidified culture media (\%)

\begin{tabular}{lccccc}
\hline \multirow{2}{*}{$\mathrm{pH} /$ Interaction } & $\begin{array}{c}\text { Incubation time } \\
\text { / } \mathrm{pH}\end{array}$ & $\begin{array}{c}\text { L. plantarum AKK-30 } \\
(\mathrm{Lp})\end{array}$ & $\begin{array}{c}\text { S. cerevisiae B-18 } \\
(\mathrm{Sc})\end{array}$ & $\begin{array}{c}\text { Lp+Sc Consortia } \\
(\text { Lp AKK-30) }\end{array}$ & $\begin{array}{c}\text { Lp+Sc Consortia } \\
(\text { Sc B-18) }\end{array}$ \\
\hline $\mathrm{pH} 2^{\mathrm{x})}$ & $0 \mathrm{~min}$ & $100.00 \pm 0.00$ & $100.00 \pm 0.00$ & $100.00 \pm 0.00$ & $100.00 \pm 0.00$ \\
& 45 & $0.37 \pm 0.39$ & $38.66 \pm 2.48$ & $0.69 \pm 0.07$ & $49.69 \pm 10.54$ \\
& 90 & $0.08 \pm 0.13$ & $3.39 \pm 0.48$ & $0.34 \pm 0.04$ & $13.02 \pm 1.33$ \\
$\mathrm{pH} 3^{\mathrm{x})}$ & 0 & $100.00 \pm 0.00$ & $100.00 \pm 0.00$ & $100.00 \pm 0.00$ & $100.00 \pm 0.00$ \\
& 45 & $0.26 \pm 0.15$ & $118.34 \pm 15.43$ & $1.56 \pm 0.12$ & $106.59 \pm 5.37$ \\
& 90 & $0.30 \pm 0.43$ & $98.71 \pm 7.70$ & $2.15 \pm 0.08$ & $89.51 \pm 6.78$ \\
\hline Average & $\mathrm{pH}$ & $0.23 \pm 0.30^{\mathrm{c}}$ & $21.07 \pm 19.33^{\mathrm{b}}$ & $0.52 \pm 0.20^{\mathrm{c}}$ & $31.16 \pm 20.81^{\mathrm{b}}$ \\
Isolates* Time & $\mathrm{pH}$ & $0.28 \pm 0.29^{\mathrm{c}}$ & $109.31 \pm 16.70^{\mathrm{a}}$ & $1.86 \pm 0.34^{\mathrm{c}}$ & $98.05 \pm 10.84^{\mathrm{a}}$ \\
\hline Average & $45 \mathrm{~min}$ & $0.31 \pm 0.27^{\mathrm{b}}$ & $79.77 \pm 46.20^{\mathrm{a}}$ & $1.13 \pm 0.49^{\mathrm{b}}$ & $78.08 \pm 31.82^{\mathrm{a}}$ \\
$\mathrm{pH}^{*}$ Isolates & $90 \mathrm{~min}$ & $0.19 \pm 0.31^{\mathrm{b}}$ & $50.61 \pm 51.77^{\mathrm{a}}$ & $1.25 \pm 1.00^{\mathrm{b}}$ & $51.13 \pm 42.27^{\mathrm{a}}$ \\
\hline
\end{tabular}

Note: ${ }^{\mathrm{x}} \mathrm{pH}$ effect indicated the significant difference, viability of probiotics in $\left.\mathrm{pH} 3>\mathrm{pH} 2(\mathrm{p}=0.02) .{ }^{*}\right)$ Means in the same row with different superscripts differ significantly $(\mathrm{p}<0.05)$.

Table 5. Viability of probiotic isolates on gastric juice and bile salt

\begin{tabular}{|c|c|c|c|c|c|c|}
\hline \multirow{2}{*}{ Viability of isolate $(\%)^{*}$} & \multicolumn{3}{|c|}{ Incubation time in gastric juice } & \multicolumn{3}{|c|}{ Incubation time in bile salt } \\
\hline & $0 \min$ & $15 \mathrm{~min}$ & $45 \mathrm{~min}$ & $0 \mathrm{~min}$ & $120 \mathrm{~min}$ & $180 \mathrm{~min}$ \\
\hline Lp AKK-30 & $100.0 \pm 0.0$ & $17.9 \pm 1.26^{\mathrm{b}}$ & $0.09 \pm 0.11$ & $100.0 \pm 0.0$ & $82.4 \pm 1.26^{\mathrm{b}}$ & $135.5 \pm 69.39$ \\
\hline Sc B-18 & $100.0 \pm 0.0$ & $96.0 \pm 15.76^{\mathrm{a}}$ & $\mathrm{uc}^{* *}$ & $100.0 \pm 0.0$ & $20.7 \pm 6.46^{\mathrm{b}}$ & $12.07 \pm 1.88$ \\
\hline Consortia (Lp AKK-30) & $100.0 \pm 0.0$ & $0.15 \pm 0.11^{\mathrm{b}}$ & $0.13 \pm 0.05$ & $100.0 \pm 0.0$ & $180.2 \pm 75.73^{\mathrm{a}}$ & $\mathrm{uc}^{* *}$ \\
\hline Consortia (Sc B-18) & $100.0 \pm 0.0$ & $102.5 \pm 9.07^{a}$ & $91.5 \pm 36.47$ & $100.0 \pm 0.0$ & $48.9 \pm 15.81^{\mathrm{b}}$ & $58.0 \pm 5.76$ \\
\hline
\end{tabular}

Note: ${ }^{*}$ Means in the same row with different superscripts differ significantly $(\mathrm{p}<0.05) .{ }^{* *}$ uc denotes uncountable colony $(>300$ cfu/mL). Viability data of cultures incubated after 180 minutes were excluded in statistical analysis.

Table 6. Nitrogen retention and metabolizable energy of quail diet supplemented with probiotics

\begin{tabular}{|c|c|c|c|c|c|c|}
\hline \multirow[b]{2}{*}{ Treatments } & \multicolumn{6}{|c|}{ Variables } \\
\hline & $\begin{array}{l}\text { Retention of } \\
\text { nitrogen }(\mathrm{g})\end{array}$ & $\begin{array}{l}\text { Retention of } \\
\text { nitrogen (\%) }\end{array}$ & $\operatorname{AME}\left(\mathrm{kcal} \mathrm{kg}^{-1}\right)$ & TME $\left(\mathrm{kcal} \mathrm{kg}^{-1}\right)$ & AMEn $\left(\mathrm{kcal} \mathrm{kg}^{-1}\right)$ & TMEn $\left(\mathrm{kcal} \mathrm{kg}^{-1}\right)$ \\
\hline Control & $183.19 \pm 26.98$ & $54.15 \pm 7.83$ & $2622.59 \pm 65.10$ & $2885.57 \pm 63.67$ & $2609.82 \pm 64.01$ & $2872.80 \pm 62.42$ \\
\hline Lp & $210.13 \pm 32.15$ & $59.94 \pm 8.76$ & $2637.46 \pm 59.14$ & $2891.32 \pm 50.71$ & $2623.33 \pm 58.20$ & $2877.18 \pm 49.41$ \\
\hline Sc & $202.43 \pm 49.11$ & $59.48 \pm 20.38$ & $2598.62 \pm 139.87$ & $2857.58 \pm 146.73$ & $2584.59 \pm 137.60$ & $2843.55 \pm 143.74$ \\
\hline $\mathrm{Lp}+\mathrm{Sc}$ & $169.10 \pm 45.09$ & $55.49 \pm 15.60$ & $2500.62 \pm 123.33$ & $2790.32 \pm 98.64$ & $2487.54 \pm 123.99$ & $2777.24 \pm 98.94$ \\
\hline Commercial & $219.63 \pm 55.79$ & $68.40 \pm 15.29$ & $2590.22 \pm 103.88$ & $2868.21 \pm 91.47$ & $2574.09 \pm 103.03$ & $2852.08 \pm 90.77$ \\
\hline Average & $196.89 \pm 44.22$ & $59.49 \pm 14.26$ & $2589.90 \pm 107.44$ & $2858.60 \pm 96.59$ & $2575.87 \pm 106.63$ & $2844.57 \pm 95.38$ \\
\hline
\end{tabular}

Note: Control= without treatment (as negative control), Lp=L. plantarum AKK-30, Sc=S. cerevisiae B-18, Lp+Sc= combination of $L$. plantarum $\mathrm{AKK}-30$ and S. cerevisiae B-18, Commercial= commercial probiotic consisted of L. plantarum and S. cerevisiae (as a positive control). AME= apparent metabolizable energy, $\mathrm{TME}=$ true metabolizable energy, $\mathrm{AMEn}=$ apparent metabolizable energy corrected by $\mathrm{N}$-energy, TMEn= true metabolizable energy corrected by N-energy. 


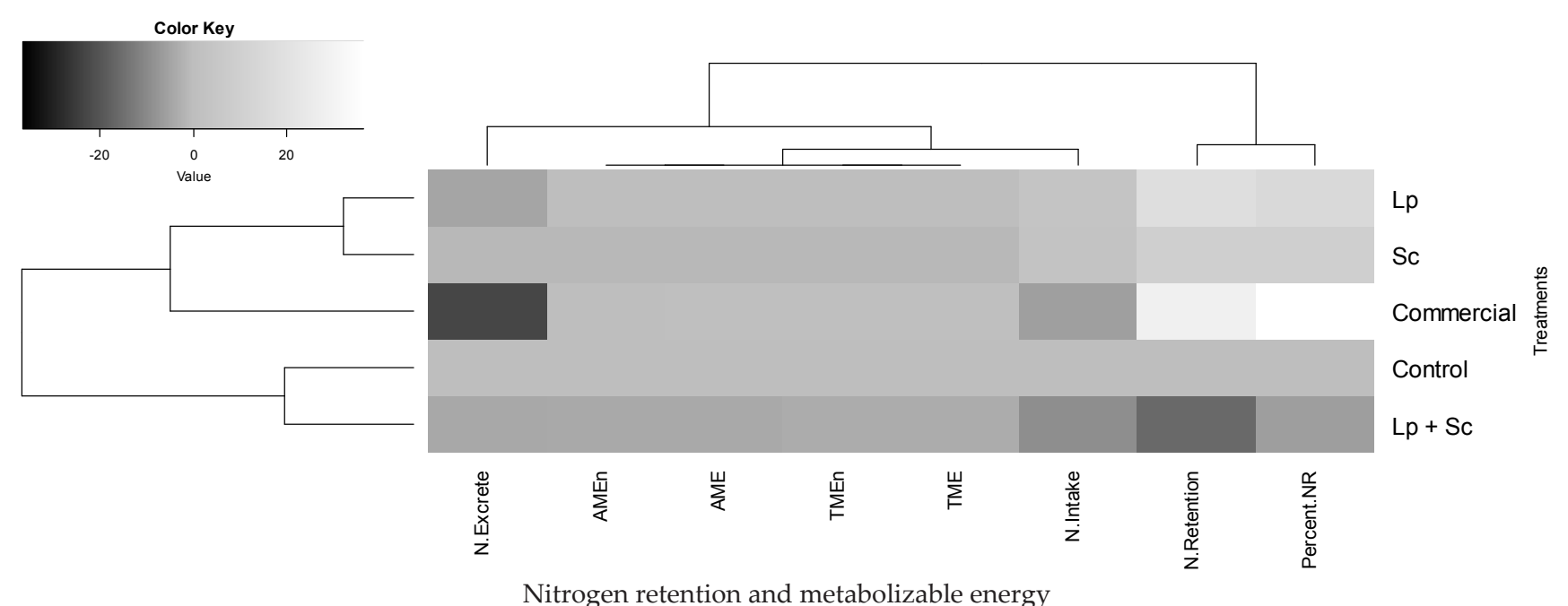

Nitrogen retention and metabolizable energy

Figure 1. Dendro-heatmap visualized interrelationship between nitrogen retention and metabolizable energy influenced by the treatments. Control= without treatment (as negative control), $\mathrm{Lp}=$ L. plantarum $\mathrm{AKK}-30, \mathrm{Sc}=\mathrm{S}$. cerevisiae $\mathrm{B}-18, \mathrm{Lp}+\mathrm{Sc}=\mathrm{combination}$ of L. plantarum AKK-30 and S. cerevisiae B-18, Commercial= commercial probiotic consisted of L. plantarum and S. cerevisiae (as positive control). AME $=$ apparent metabolizable energy, TME= true metabolizable energy, AMEn= apparent metabolizable energy corrected by N-energy, TMEn= true metabolizable energy corrected by N-energy. N-excreta= nitrogen content in excreta, N. Retention= nitrogen retention, Percent.NR= percentage of nitrogen retention.

the same cluster with the control but in a different cluster from the individual probiotics across all parameters (Figure 1).

\section{DISCUSSION}

Antibacterial activity against pathogenic bacteria, viability in low $\mathrm{pH}$ or bile salt, and antibiotic sensitivity are parameters that are considered in selecting probiotic candidate (de Melo Pereira et al., 2018). Gotcheva et al. (2002) reported that Lactobacillus plantarum and Candida rugosa had antibacterial activity towards $P$. aeruginosa, $S$. enteritidis, and Salmonella strains. In this study, L. plantarum AKK-30 and S. cerevisiae B-18 could inhibit S. aureus, $P$. aeruginosa, and $S$. pullorum. These found results indicate that both isolates have antibacterial substances. L. plantarum and S. cerevisiae secrete antimicrobial peptides (AMPs) namely plantaricin and saccharomycin, respectively, which have an important role for inhibiting pathogenic bacteria (Hammami et al., 2013). The mode of AMPs inhibition activity of probiotics is associated with the absorption of pathogenic bacteria on the cellmembrane receptors. The other mechanisms might correlate with the alterations of intracellular $\mathrm{pH}$ and membrane permeability (Hammami et al., 2013; Rizk et al., 2018).

Stanley et al. (2014) stated that Lactobacillus strain isolated from chicken possessed a high activity of antibiotics resistance. In the previous study, three selected broiler chicken-indigenous LAB had some degrees of antibiotic resistances against several antibiotics (Torshizi et al., 2008). The resistance of yeast isolate to antibiotic made it suitable for poultry undergoing antibiotic treatment and profitable over bacteria for therapeutic use (Syal \& Vohra, 2013). In this study, L. plantarum and S. cerevisiae were resistant to streptomycin and penicillin but not to erythromycin. Damayanti et al. (2014) revealed that $P$. acidilactici R01 isolated from broiler's GIT, showed a sensitive response to erythromycin and resistant responses to streptomycin and penicillin.

One of the main characteristics of probiotic to give advantageous health for the host is a tolerance to the environment of GIT such as acid and bile salt (Rajoka et al., 2018). Bile-salt tolerance is associated with the activity of bile salt hydrolase (BSH). BSH brake down the peptide linkage of bile acids, which removes the amino acid group from the steroid core and the unconjugated bile acids precipitate at low pH (Ooi \& Liong, 2010). In this study, both isolates could survive on bile salt after 3 hours. It would be possible to deconjugate bile salt and might be effective in reducing serum cholesterol in poultry. In the previous study, isolates Lp AKK-30 and Sc B-8 showed lowering cholesterol activities (Julendra et al., 2017; Istiqomah et al., 2018).

In gastric juice tolerant assay, the cell viability of isolate decreased while the yeast survived after 45 minutes of incubation. Moreover, the viability of Sc B-8 showed the highest level at $\mathrm{pH} 3$ after $45 \mathrm{~h}$ of incubation. These results indicate that $S$. cerevisiae is tolerant of low $\mathrm{pH}$. The ability of an isolate to survive in acid medium is influenced by many factors such as temperature, $\mathrm{pH}$, nutrient ability, and previous natural habits (Kumar \& Gopal, 2015). The viability of microorganism is closely associated with the adaptability to the environment (Sofyan et al., 2013).

Administration of probiotics in drinking water or broiler feed improves performance and affects the height and surface area of villi in the small intestine (Sharifi et al., 2012). These conditions will increase the capacity of small intestine in absorbing more nutrients. The stimulation mechanism increases digestion by probiotics in various mechanisms. Probiotics can increase the production of volatile fatty acids (VFA) consisting of acetate, propionate, and butyrate that are further 
used in the tissue as energy sources for animal (Ajuwon, 2016). In this study, probiotics inclusion did not affect metabolizable energy. In contrast, Pramudia et al. (2013) reported that the inclusion of probiotics containing LAB increased the ME value around 2600-2875 kcal kg-1 by giving feed protein. Probiotics also protect epithelial cells, stimulate enzyme activity in the digestive tract, and increase nutrient absorption (Wang \& Gu, 2010).

Even though nitrogen retention or metabolizable energy could be improved by the addition of L. plantarum AKK-30 or S. cerevisiae B-18, quails consuming a combination of isolates had a tendency of decreasing nutrient utilization. Furthermore, differences cluster between probiotics consortia and individual treatment might be associated with the antagonistic effects between L. plantarum AKK-30 and S. cerevisiae B-18. Antagonistic interaction might be associated with the possible mechanism i.e. competitiveness to digest the nutrients for growth (Kim et al., 2018). The other mechanism i.e., the cross inhibition between LAB and yeast, might be occurred. LAB produced lactic acid potentially inhibit yeast growth (Narendranath et al., 2001) or saccharomycin secreted by $S$. cerevisiae can inhibit bacteria (Branco et al. 2017). In contrast, mutual interaction between $\mathrm{LAB}$ and yeast could be found at sourdough (Sieuwerts et al., 2018) or Kefir (Stadie et al., 2013).

\section{CONCLUSION}

Probiotics consisting of L. plantarum AKK-30, S. cerevisiae B-18 or their combination could inhibit $P$. aeruginosa, S. aureus, and S. pullorum. Both isolates were resistant to streptomycin and penicillin, and tolerant to acids and bile salt. Inclusion of $L$. plantarum and $S$. cerevisiae did not affect the nutrient utilization of quail's diet. Further study is necessary to explore the nutrient (prebiotic) for optimizing the synergistic effect of L. plantarum AKK-30 and S. cerevisiae B-18.

\section{CONFLICT OF INTEREST}

The authors declared that there is no conflict of interest with any producers and organizations in relation to the material used in this experiment.

\section{ACKNOWLEDGEMENT}

The Thematic Research Program of Indonesian Institute of Sciences (LIPI) supported the experiment. The authors greatly appreciate the assistance of researchers and technicians of Bio-Feed Additive Research Group for supporting this research. We also gratefully appreciate to the "Program Bantuan Seminar Luar Negeri, Ditjen Penguatan Riset dan Pengembangan, Kemenristekdikti" for supporting our publication.

\section{REFERENCES}

Ajuwon, J.M. 2016. Toward a better understanding of mechanisms of probiotics and prebiotics action in poultry species. J. Appl. Poult. Res. 25:277-283. http://dx.doi.org/10.3382/ japr/pfv074
Arena, M.P., V. Capozzi, P. Russo, D. Drider, G. Spano, \& D. Fiocco. 2018. Immunobiosis and probiosis: antimicrobial activity of lactic acid bacteria with a focus on their antiviral and antifungal properties. Appl. Microbiol. Biotechnol. 102:9949-9958. https://doi.org/10.1007/s00253-018-9441-3

AOAC. 2005. Official Methods of Analysis of AOAC International. $18^{\text {th }}$ ed. Assoc. Off. Anal. Chem., Arlington.

Barbosa-Cánovas, G.V., E. Ortega-Rivas, P. Juliano, \& H. En. 2005. Drying: In Food Powders-Physical Properties, Processing and Functionality, First Edition; Kluwer Academic/Plenum Publishers, New York, pp. 271-304.

Bonev, B.J., J. Hooper, \& J. Parisot. 2008. Principles of assessing bacterial susceptibility to antibiotics using the agar diffusion method. J. Antimicrob. Chemother. 61:1295-1301. https://dx.doi.org/10.1093/jac/dkn090

Branco, P., D. Francisco, M. Monteiro, M.G. Almeida, J. Caldeira, N. Arneborg, N. Arneborg \& H. Albergaria. 2017. Antimicrobial properties and death-inducing mechanisms of saccharomycin, a biocide secreted by Saccharomyces cerevisiae. Appl. Microbiol. Biotechnol. 101: 159-171. https://dx.doi.org/10.1007/s00253-016-7755-6

Cohort. 2008. Costat-Coplot Version 6.311. Cohort software798 light house Ave. PMB320, Monterey, CA93940, and USA. http://www.cohort.com/DownloadCoStatPart2.html.

Cox, C.M., \& R.A. Dalloul. 2015. Immunomodulatory role of probiotics in poultry and potential in ovo application. Benef. Microbes. 6: 45-52. https://doi.org/10.3920/ BM2014.0062

de Melo Pereira, G.V., B. de Oliveira Coelho, A.I.M. Júnior, V. Thomaz-Soccol, \& C.R. Soccol. 2018. How to select a probiotic? A review and update of methods and criteria. Biotechnol. Adv. 36: 2060-2076. https://doi.org/10.1016/j. biotechadv.2018.09.003

Damayanti, E., H. Julendra, A. Sofyan \& S.N. Hayati. 2014. Bile salt and acid tolerant of lactic acid bacteria isolated from proventriculus of broiler chicken. Med. Pet. 37:80-86. https://doi.org/10.5398/medpet.2014.37.2.80

Gotcheva, V., E. Hristozova, T. Hristozova, M. Guo, Z. Roshkova, \& A. Angelov. 2002. Assessment of potential probiotic properties of lactic acid bacteria and yeast strains. Food Biotechnol. 16: 211-225. https://doi.org/10.1081/ FBT-120016668

Goutard FL, M. Bordier, C. Calba, E. Erlacher-Vindel, D. Góchez, K. de Balogh, C. Benigno, W. Kalpravidh, F. Roger, \& S. Vong. 2017. Antimicrobial policy interventions in food animal production in South East Asia. Br. Med. J. 358:36-41. https://doi.org/10.1136/bmj.j3544

Farrell, D.J., S.I. Atmamihardja, \& R.A.E. Pym. 1982. Calorimetric measurements of the energy and nitrogen metabolism of Japanese quail. Br. Poult. Sci. 23: 375-382. https://doi.org/10.1080/00071688208447971

Hammami, R., B. Fernandez, C. Lacroix, \& I. Fliss. 2013. Anti-infective properties of bacteriocins: an update. Cell. Mol. Life Sci. 70: 2947-2967. https://doi.org/10.1007/ s00018-012-1202-3

Hatoum, R., S. Labrie, \& I. Fliss. 2012. Antimicrobial and probiotic properties of yeasts: from fundamental to novel applications. Front. Microbiol. 3: 421. https://doi.org/10.3389/ fmicb.2012.00421

Harimurti S., \& W. Hadisaputro. 2015. Probiotics in Poultry. In: Liong MT. (eds) Beneficial Microorganisms in Agriculture, Aquaculture and Other Areas. Microbiology Monographs, Vol. 29. Springer International Publishing, Switzerland. https://doi.org/10.1007/978-3-319-23183-9_1

Huyghebaert, G., R. Ducatelle, \& F. Van Immerseel. 2011. An update on alternatives to antimicrobial growth promoters for broilers. Vet. J. 187:182-188. https://doi.org/10.1016/j. tvj1.2010.03.003

Istiqomah, L., M. Anwar, A.S. Anggraeni, \& E. Damayanti. 
2018. Cholesterol assimilation of Sacharomyces cerevisiae B-18 isolated from gastrointestinal tract of Javanese duck. J. Indon. Trop. Anim. Agric. 43: 149-158. https://doi. org/10.14710/jitaa.43.2.149-158

Julendra, H., A.E. Suryani, L. Istiqomah, E. Damayanti, M. Anwar, \& N. Fitriani. 2017. Isolation of lactic acid bacteria with cholesterol-lowering activity from digestive tracts of Indonesian native chicken. Med. Pet. 40: 35-41. https://doi. org/10.1099/0022-1317-78-6-1357

Kim, H., E.J. Oh, S.T. Lane, W.H. Lee, J.H. Cate, \& Y.S. Jin. 2018. Enhanced cellobiose fermentation by engineered Saccharomyces cerevisiae expressing a mutant cellodextrin facilitator and cellobiose phosphorylase. J. Biotechnol. 275: 53-59. https://doi.org/10.1016/j.jbiotec.2018.04.008

Kumar, B. L., \& D.S. Gopal. 2015. Effective role of indigenous microorganisms for sustainable environment. Biotech. 5: 867-876. https://doi.org/10.1007/s13205-015-0293-6

Martin, R.S.H., E.B. Laconi, A. Jayanegara, A. Sofyan, \& L. Istiqomah. 2018. Activity and viability of probiotic candidates consisting of lactic acid bacteria and yeast isolated from native poultry gastrointestinal tract. AIP Conference Proc. 2021: 070012. https://doi.org/10.1063/1.5062810

Ministry of Agriculture - Republic of Indonesia [MARI]. 2017. Peraturan Menteri Pertanian Republik Indonesia Nomor 14/Permentan/PK.350/5/2017 tentang Klasifikasi Obat Hewan (Animal Medicine Classification Act). Retrieved from: http://perundangan.pertanian.go.id. [12 May 2017].

Narendranath, N.V., K.C. Thomas, \& W.M. Ingledew. 2001. Effects of acetic acid and lactic acid on the growth of Saccharomyces cerevisiae in a minimal medium. J. Indust. Microbiol. Biotechnol. 26: 171-177. https://doi.org/10.1038/ sj.jim. 7000090

Ooi, L.G. \& M.T. Liong. 2010. Cholesterol-lowering effects of probiotics and prebiotics: a review of in vivo and in vitro findings. Int. J. Mol. Sci. 11:2499-2522. https://doi. org/10.3390/ijms11062499

Rajoka, M.S.R., H.F. Hayat, S. Sarwar, H.M. Mehwish, F. Ahmad, N. Hussain, S.Z.H. Shah, M. Khurshid, M. Siddiqu, \& J. Shi. 2018. Isolation and evaluation of probiotic potential of lactic acid bacteria isolated from poultry intestine. Microbiology 87: 116-126. https://doi. org/10.1134/S0026261718010150

R Core Team. 2015. R: a language and environment for statistical computing. R Foundation for Statistical Computing, Vienna, Austria. Retrieved on 31 October 2015 from http:// www.R-project.org/

Rizk, Z., Y. El Rayess, C. Ghanem, F. Mathieu, P. Taillandier, \& N. Nehme. 2018. Identification of multiple-derived peptides produced by Saccharomyces cerevisiae involved in malolactic fermentation inhibition. FEMS Yeast Res. 18: foy080. https://doi.org/10.1093/femsyr/foy080
Ronquillo, M.G., \& J.C.A. Hernandez. 2017. Antibiotic and synthetic growth promoters in animal diets: review of impact and analytical methods. Food Control 72: 255-267. https://doi.org/10.1016/j.foodcont.2016.03.001

Sibbald, I. R., \& M.S. Wolynetz. 1985. Relationships between estimates of bioavailable energy made with adult cockerels and chicks: effects of feed intake and nitrogen retention. Poult. Sci. 64: 127-138. https://doi.org/10.3382/ps.0640127

Sharifi, S.D., A.Dibamehr, H. Lotfollahian \& B. Baurhoo. 2012 Effects of flavomycin and probiotic supplementation to diets containing different sources of fat on growth performance, intestinal morphology, apparent metabolizable energy, and fat digestibility in broiler chickens. Poult. Sci. 91: 918-927. https://doi.org/10.3382/ps.2011-01844

Sieuwerts, S., P.A. Bron, \& E.J. Smid. 2018. Mutually stimulating interactions between lactic acid bacteria and Saccharomyces cerevisiae in sourdough fermentation. LWT - Food Sci. Technol. 90: 201-206. https://doi.org/10.1016/j. lwt.2017.12.022

Sofyan, A., A.N. Aswari, T. Purwoko, \& E. Damayanti. 2013. Screening of lactic acid bacteria from rumen liquor and king grass silage as well as their antibacterial activities. Med. Pet. 36: 216. http://dx.doi.org/10.5398/medpet.2013.36.3.216

Stadie, J., A. Gulitz, M.A. Ehrmann, \& R.F. Vogel. 2013. Metabolic activity and symbiotic interactions of lactic acid bacteria and yeasts isolated from water kefir. Food Microbiol. 35: 92-98. https://doi.org/10.1016/j. fm.2013.03.009

Stanley, D., R.J. Hughes \& R.J. Moore. 2014. Microbiota of the chicken gastrointestinal tract: influence on health, productivity and disease. Appl. Microbiol. Biotechnol. 98: 43014310. https://doi.org/10.1007/s00253-014-5646-2

Syal, P. \& A. Vohra. 2013. Probiotic potential of yeasts isolated from traditional Indian fermented foods. Int. J. Microbiol. Res. 5:390-398. http://dx.doi. org/10.9735/0975-5276.5.2.390-398

Torshizi, M.A.K., S.H. Rahimi, N. Mojgani, S. Esmaeilkhanian, \& J.L. Grimes. 2008. Screening of indigenous strains of lactic acid bacteria for development of a probiotic for poultry. Asian-Australas. J. Anim. Sci. 21: 1495-1500. https://doi. org/10.5713/ajas.2008.80081

Wang, Y., \& Q. Gu. 2010. Effect of probiotic on growth performance and digestive enzyme activity of Arbor Acres broilers. Res. Vet. Sci. 89: 163-167. https://doi.org/10.1016/j. rvsc.2010.03.009

Zhang, Z., F. Murtagh, S. Van Poucke, S. Lin, \& P. Lan. 2017. Hierarchical cluster analysis in clinical research with heterogeneous study population: highlighting its visualization with R. Ann. Transl. Med. 5: 1-11. http://dx.doi. org/10.21037/atm.2017.02.05 